Jurnal Keperawatan Silampari

Volume 5, Nomor 1, Desember 2021

e-ISSN: 2581-1975

p-ISSN: 2597-7482

DOI: https://doi.org/10.31539/jks.v5i1.1476

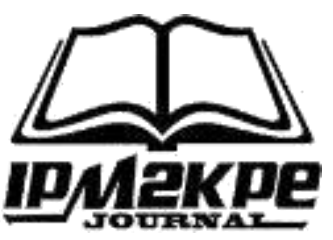

\title{
SISTEM REMUNERASI TERHADAP MOTIVASI KERJA DAN KINERJA PERAWAT
}

\author{
Monita Fenny Sudarsono ${ }^{1}$, Hadi Masyurrosyidi ${ }^{2}$, Djazuly Chalidyanto ${ }^{3}$ \\ Universitas Airlangga ${ }^{1,2,3}$ \\ monita.sudarsono-2019@ fkm.unair.ac.id ${ }^{1}$
}

\begin{abstract}
ABSTRAK
Penelitian ini bertujuan untuk mengetahui pengaruh sistem remunerasi terhadap motivasi kerja perawat dan kinerja perawat di Rumah Sakit Swasta Jawa Timur. Metode penelitian yang digunakan adalah metode observasional dengan rancang bangun cross-sectional. Hasil dari penelitian ini yaitu sistem remunerasi terhadap motivasi menunjukkan nilai signifikansi sebesar $0.022(\alpha=0.05)$. Adapun motivasi terhadap kinerja menunjukkan nilai signifikansi $0.001(\alpha=0.05)$. Sementara itu, sistem remunerasi tidak berpengaruh signifikan terhadap kinerja dengan nlai signifikansi 0.487. Simpulan, sistem remunerasi memiliki pengaruh yang signifikan pada motivasi perawat dan motivasi memiliki pengaruh yang signifikan terhadap kinerja perawat di Rumah Sakit Swasta Jawa Timur, sehingga sistem remunerasi dapat mempengaruhi kinerja melalui motivasi.
\end{abstract}

Kata Kunci: Kinerja, Motivasi, Perawat, Sistem Remunerasi

\section{ABSTRACT}

This study aims to determine the effect of the remuneration system on nurses' work motivation and nurse performance in East Java Private Hospitals. The research method used is an observational method with a cross-sectional design. The result of this research is that the remuneration system on motivation shows a significance value of $0.022(\alpha=0.05)$. The reason for performance offers a significance value of $0.001(\alpha=0.05)$. Meanwhile, the remuneration system has no significant effect on performance, with a significance value of 0.487. In conclusion, the remuneration system has a significant influence on motivation. Motivation has a significant impact on the performance of nurses in East Java Private Hospitals so that the remuneration system can affect motivation.

Keywords: Performance, Motivation, Nurse, Remuneration System

\section{PENDAHULUAN}

Rumah sakit melibatkan berbagai tenaga profesional kesehatan dalam proses pemberian pelayanan kepada pasien. Perawat merupakan bagian tak terpisahkan dari tim profesional kesehatan serta memainkan peran kunci dalam menjaga kualitas layanan rumah sakit. Kompetensi yang memadai sangat penting bagi perawat untuk memberikan asuhan dan layanan keperawatan yang berkualitas, sehingga meningkatkan kepuasan pasien. Tingkat kepuasan pasien timbul karena adanya kepuasan dalam pemberian asuhan keperawatan dan pelayanan kesehatan. Keperawatan yang baik dan benar memberikan manfaat perawatan kesehatan dengan berkontribusi pada kualitas tertinggi dari asuhan 
keperawatan dan meningkatkan kesembuhan pasien. Beberapa studi menyatakan bahwa kinerja perawat merupakan faktor terpenting dalam menentukan kualitas layanan kesehatan (Hidayah et al., 2020).

Studi di salah satu rumah sakit swasta di Jawa Timur menunjukkan bahwa hasil penilaian kinerja perawat menunjukkan bahwa sebanyak 55\% ketidakpuasan pasien berasal dari asuhan keperawatan yang mengakibatkan kinerja perawat dinilai harus ditingkatkan kembali (Dyah et al., 2020). Hal ini didukung dengan penelitian di Rumah Sakit Dr. R. Sosodoro Djatikoesoemo Bojonegoro Jawa Timur yang menunjukkan bahwa kelengkapan dokumen rekam medis pada dokumentasi asuhan keperawatan rawat inap masih mencapai ketuntasan $75 \%$ dan $25 \%$ sisanya masih belum lengkap, yang menunjukkan perlunya peningkatan kinerja perawat dalam mencapai standar pelayanan minimal rumah sakit (Pratama et al., 2018).

Beberapa faktor yang mempengaruhi penurunan maupun peningkatan kinerja perawat dalam pelayanan kesehatan adalah sistem remunerasi dan motivasi kerja perawat (Hadiyanto, 2020). Berdasarkan studi di Rumah Sakit Paru Dr. M. Goenawan Partowidigdo Cisarua Bogor menunjukkan bahwa rumah sakit yang memiliki sistem remunerasi lebih berpotensi meningkatkan motivasi pegawai dan meningkatkan kualitas pelayanan di rumah sakit dibanding rumah sakit yang tidak mempunyai sistem remunerasi berbasis kinerja (Hartono et al., 2019). Rumah sakit harus menyadari bahwa mereka harus memperhatikan keseimbangan antara kontribusi pegawai terhadap organisasi dengan kontribusi organisasi terhadap kesejahteraan pegawai tersebut. Salah satu faktor yang mempengaruhi kepuasan kerja pegawai adalah income yang diterima. Reward yang langsung juga berpotensi memotivasi perbaikan kinerja individu. Sebaliknya, apabila sistem penggajian yang diterapkan kurang sesuai, maka dapat merusak motivasi pegawai dalam bekerja (Azizah et al., 2017).

Remunerasi merupakan imbalan atau balas jasa yang diberikan kepada tenaga kerja karena prestasi yang telah diberikannya dalam rangka mencapai tujuan organisasi (Wati, 2018). Semua pembayaran pada seorang pegawai akan dihitung sebagai remunerasi. Remunerasi dapat berupa gaji atau upah, honorarium, tunjangan-tunjangan, wewenang, dan apresiasi. Sistem remunerasi pegawai yang didasarkan pada beban kerja dan tanggung jawab masing-masing pegawai serta kinerja pegawai diharapkan dapat meminimalisir terjadinya penyalahgunaan wewenang dan meningkatkan kinerja pegawai di lingkungan rumah sakit (Permatasari et al., 2021).

Sistem remunerasi mempunyai beberapa komponen yaitu yang berbentuk uang seperti gaji atau upah, bonus, komisi dan reward lainnya yang diberikan dalam bentuk uang. Sedangkan imbalan non uang dapat dirupakan dengan program-program proteksi, kesempatan berpartisipasi dalam membuat keputusan, penghargaan, sertifikat ataupun sekedar perhatian (Mendes et al., 2017).

Selain sistem remunerasi, motivasi kerja perawat juga mempunyai peran dalam meningkatkan kinerja perawat. Dalam organisasi kesehatan, motivasi kerja merupakan ukuran penting dari respon profesional kesehatan terhadap tantangan dan tuntutan yang semakin meningkat (Tong, 2018). Motivasi dikenal sebagai proses yang dimulai dengan inspirasi untuk melakukan dan memberi energi sampai akhir. Motivasi adalah konsep yang digunakan untuk menggambarkan keadaan eksternal yang mengilhami perilaku khusus dan respons internal yang mengungkapkan perilaku itu. Dalam konteks organisasi, motivasi dijelaskan sebagai stimulus perilaku kerja, yang menyalurkan upaya pekerja untuk mencapai tujuan organisasi. Motivasi kerja adalah hasil interaksi antara individu (proses 
psikologis internal), lingkungan kerja mereka (proses transaksional) dan kesesuaian antara interaksi ini dengan konteks masyarakat (Baljoon et al., 2018).

Sebuah studi menjelaskan bahwa sistem remunerasi dapat berpengaruh secara langsung terhadap peningkatan kinerja perawat dikarenakan sistem remunerasi secara langsung mencegah turnover perawat dan meningkatkan kinerja perawat (Hidayah \& Dewi, 2021). Di sisi lain, penelitian yang dilakukan oleh Jalal \& Zaheer (2017) menjelaskan bahwa sistem remunerasi tidak memiliki pengaruh secara langsung terhadap kinerja akan tetapi hal tersebut sangat penting dalam meningkatkan motivasi karyawan di dalam sebuah organisasi sehingga akan memiliki dampak signifikan terhadap kinerja. Kinerja karyawan yang tinggi mencerminkan tingkat produktifitas dan efektifitas organisasi.

Penelitian tentang renumerasi sudah pernah dilakukan, namun fokuspada penelitian ini adalah melihat pengaruh sistem renumerasi terhadap motivasi dan kinerja perawat. Selain itu, penelitian tentang renumerasi ini belum pernah dilakukan di Rumah Sakit Swasta Jawa Timur.

\section{METODE PENELITIAN}

Penelitian ini merupakan penelitian observasional dengan rancang bangun cross sectional. Lokasi penelitian adalah rumah sakit swasta di Jawa Timur. Waktu penelitian mulai pada bulan Mei sampai dengan Juni 2020. Populasi penelitian ini adalah semua perawat yang bekerja di Rumah Sakit Swasta Jawa Timur. Sampel dari penelitian ini adalah perawat di rumah sakit swasta yang masih dalam jangkauan peneliti, responden bersedia mengisi inform consent dan kuesioner penelitian. Sampel dihitung menggunakan rumus simple random sampling didapatkan sample sebesar 79 responden $(\alpha=0.05)$.

Data sekunder diambil dari dokumen pada manajemen rumah sakit swasta. Pengambilan data primer yaitu dengan membagikan kuesioner dan wawancara kepada responden. Kuesioner telah dilakukan uji validitas dan realibilitas. Kuesioner berisi tentang pendapat mengenai sistem remunerasi, motivasi dan kinerja perawat. Responden diminta kesediannya dengan menandatangi informed consent sebelum mengisi questioner yang telah terlampir, kemudian data diolah dengan menggunakan uji regresi logistik ganda.

Penelitian ini dilakukan untuk menjawab bagaimana pengaruh sistem remunerasi terhadap motivasi, motivasi terhadap kinerja pegawai, dan pengaruh remunerasi terhadap motivasi dan kinerja pegawai di Rumah Sakit Swasta di Jawa Timur.

\section{HASIL PENELITIAN}

Tabel. 1

Karakteristik Perawat

\begin{tabular}{llcccc}
\hline \multirow{2}{*}{ Karakteristik Responden } & \multicolumn{4}{c}{ Kinerja Perawat } \\
\cline { 3 - 6 } & & \multicolumn{2}{c}{ Rendah } & \multicolumn{2}{c}{ Tinggi } \\
\cline { 3 - 6 } & Caring & $\mathrm{n}$ & $(\%)$ & $\mathrm{n}$ & $(\%)$ \\
\hline \multirow{2}{*}{ Unit } & Outpatient & 17 & $(32.1)$ & 36 & $(67.9)$ \\
& Pria & 12 & $(46.2)$ & 14 & $(53.8)$ \\
\hline Jenis Kelamin & Wanita & 4 & $(50.0)$ & 4 & $(50.0)$ \\
& <35 Tahun & 25 & $(35.2)$ & 46 & $(64.8)$ \\
\hline Usia & $\geq 35$ Tahun & 25 & $(39.7)$ & 38 & $(60.3)$ \\
& Diploma & 4 & $(25.0)$ & 12 & $(75.0)$ \\
\hline Pendidikan & Sarjana & 12 & $(27.9)$ & 31 & $(72.1)$ \\
& $<5$ Tahun & 17 & $(47.2)$ & 19 & $(52.8)$ \\
\hline Lama Kerja & $\geq 5$ Tahun & 17 & $(53.1)$ & 15 & $(46.9)$ \\
& & 12 & $(25.5)$ & 35 & $(74.5)$
\end{tabular}




\begin{tabular}{llcccc}
\hline Status & Belum Menikah & 8 & $(42.1)$ & 11 & $(57.9)$ \\
& Menikah & 21 & $(35.0)$ & 39 & $(65.0)$ \\
\hline Sistem Remunerasi & Kurang Puas & 20 & $(46.5)$ & 23 & $(53.5)$ \\
& Puas & 9 & $(25.0)$ & 27 & $(75.0)$ \\
\hline Motivasi & Rendah & 27 & $(64.3)$ & 15 & $(35.7)$ \\
& Tinggi & 2 & $(5.4)$ & 35 & $(94.6)$ \\
\hline
\end{tabular}

Berdasarkan tabel 1 dapat diketahui bahwa kinerja perawat tertinggi terdapat pada unit perawatan IGD, ICU, NICU, dan unit rawat jalan sebanyak 36 responden (67.9\%), wanita sebanyak 46 responden $(64.8 \%)$, usia kurang dari 35 tahun sebanyak 38 responden (60.3\%), pendidikan diploma sebanyak 31 responden $(72.1 \%)$, lama bekerja lebih dari 5 tahun sebanyak 35 responden (74.5\%), status menikah sebanyak 39 responden $(65.0 \%)$. Sedangkan pada sistem remunerasi yang diberikan organisasi, responden memberikan pernyataan puas sebanyak 27 responden $(75.0 \%)$, motivasi tinggi 35 responden $(94,6)$.

Tabel. 2

Pengaruh Sistem Remunerasi dan Motivasi terhadap Kinerja Perawat

\begin{tabular}{lcccc}
\hline \multirow{2}{*}{\multicolumn{1}{c}{ Varibel Independen }} & \multicolumn{4}{c}{ Kinerja Perawat } \\
\cline { 2 - 5 } & S.E & $\rho$ & $\beta$ & CI 95\% \\
\hline Sistem Remunerasi & 0.725 & 0.487 & 0.504 & 0.400 to 6.862 \\
Motivasi & 0.844 & 0.000 & 3.454 & 1.044 to 6.366 \\
Sistem Remunerasi-Motivasi* & 0.468 & 0.022 & 2.933 & 1.172 to 7.344 \\
\hline
\end{tabular}

Berdasarkan tabel 2 diketahui bahwa sistem remunerasi tidak memiliki pengaruh signifikan terhadap kinerja perawat dengan $\rho$-value 0.487. Penelitian ini menunjukkan bahwa sistem remunerasi tidak memilik pengaruh langsung terhadap kinerja perawat. Sedangkan pada variabel motivasi memiliki $\rho$-value 0.000 dengan $\beta 3.454$, hal ini menunjukkan bahwa perawat memiliki kinerja 3 kali lebih baik pada perawat yang memiliki motivasi tinggi dibandingkan perawat yang memiliki motivasi rendah. Selain itu, pengaruh variabel sistem remunerasi terhadap motivasi memiliki $\rho$-value 0.022 dengan nilai $\beta 2.933$ sehingga menunjukkan bahwa perawat memiliki motivasi 2 kali lebih tinggi pada perawat yang menyatakan puas terhadap sistem remurasi.

Dari hasil uji statistik didapatkan gambaran bahwa sistem remunerasi memiliki pengaruh signifikan pada motivasi kerja perawat di Rumah Sakit Swasta Jawa Timur. Selanjutnya, motivasi kerja perawat akan berdampak positif pada kinerja perawat sehingga organisasi dapat mengukur tingkat produktifitas karyawan yang akan berkontribusi besar pada produktifitas organisasi. Kesimpulan tersebut dapat dilihat pada Gambar 1. berikut ini:

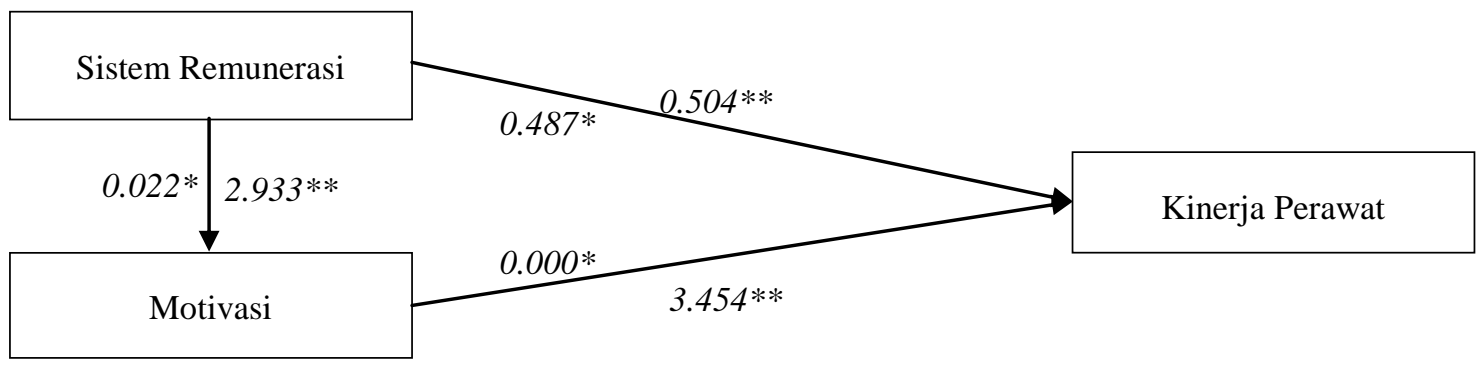

* Sig. (2-tailed) <0.05; ** Beta (B)

Gambar. 1

Model dan Hasil Penelitian 
Model tersebut menjelaskan bahwa sistem remunerasi berpengaruh secara langsung dan signifikan terhadap motivasi. Sebagai tambahan, motivasi juga memiliki pengaruh secara langsung dan signifikan terhadap kinerja perawat. Sedangkan sistem remunerasi memiliki pengaruh secara langsung terhadap kinerja perawat namun tidak berpengaruh secara signifikan.

\section{PEMBAHASAN}

\section{Pengaruh Sistem Remunerasi terhadap Motivasi Kerja Perawat}

Sistem remunerasi mempunyai beberapa komponen yaitu yang berbentuk uang seperti gaji atau upah, bonus, komisi dan reward lainnya yang diberikan dalam bentuk uang. Sedangkan imbalan non uang dapat dirupakan dengan program-program proteksi, kesempatan berpartisipasi dalam membuat keputusan, penghargaan, sertifikat ataupun sekedar perhatian (Mendes et al., 2017). Semua komponen sistem remunerasi tersebut dirancang untuk memberikan kesejahteraan kepada perawat sehingga perawat dalam memberikan keahlian terbaiknya dalam merawat pasien.

Remunerasi penting bagi karyawan sebagai individu karena besarnya remunerasi mencerminkan ukuran karya mereka diantara para perawat itu sendiri dalam memberikan asuhan keperawatan dan pelayanan kesehatan kepada pasien. Sistem remunerasi merupakan salah satu bentuk reward atas kinerja perawat yang dapat meningkatkan motivasi perawat dalam bekerja, jika kinerja perawat baik maka nilai remunerasinya akan tinggi. Begitupula sebaliknya, jika kinerja perawat kurang baik maka nilai remunerasinya rendah (Muthmainnah et al., 2018).

Penelitian ini menunjukkan hasil yang menyatakan bahwa sistem remunerasi berpengaruh secara signifikan terhadap motivasi kerja perawat. Hal ini sejalan dengan penelitian yang dilakukan oleh Baljoon et al., (2018) yang menyatakan bahwa $83 \%$ perawat meningkat motivasi kerjanya ketika mendapatkan nilai remunerasi yang lebih tinggi dibanding sebelumnya.

\section{Pengaruh Motivasi Kerja terhadap Kinerja Perawat}

Motivasi kerja adalah hasil interaksi antara individu (proses psikologis internal), lingkungan kerja mereka (proses transaksional) dan kesesuaian antara interaksi ini dengan konteks masyarakat (Baljoon et al., 2018).

Motivasi merupakan beberapa faktor yang mendorong perilaku atau keinginan seseorang untuk melakukan sesuatu bentuk kegiatan yang dinyatakan dalam bentuk usaha keras atau lemah ( $\mathrm{Li}$ et al., 2018). Motivasi juga didefinisikan sebagai keadaan di mana usaha dan kemauan keras seseorang dapat diarahkan kepada pencapaian hasil-hasil atau tujuan tertentu (Lesmana \& Putri, 2017). Hasil-hasil yang dimaksud bisa berupa produktivitas, kehadiran atau perilaku kerja kreatif lainnya. Berdasarkan beberapa pengertian motivasi maka dapat dikatakan bahwa motivasi tumbuh dari diri sendiri dan berfungsi untuk mencapai suatu tujuan tertentu dan juga dapat diakibatkan oleh dorongan orang lain atau lingkungan sekitar. Tetapi motivasi yang paling baik adalah motivasi yang tumbuh dari dalam diri sendiri karena dilakukan tanpa paksaan dan setiap individu memiliki motivasi yang berbeda untuk mencapai tujuannya.

Motivasi kerja merupakan salah satu faktor yang menentukan kinerja seseorang, besar atau kecilnya pengaruh motivasi pada kinerja seseorang tergantung pada seberapa banyak intensitas motivasi yang diberikan (Maini, 2020). Motivasi kerja tampak melalui tanggung jawab dalam melakukan kerja, prestasi yang dicapainya, pengembangan diri, serta kemandirian dalam bertindak sesuai key performance indicator. 
Beberapa faktor yang mempengaruhi penurunan maupun peningkatan kinerja perawat dalam pelayanan kesehatan adalah sistem remunerasi dan motivasi kerja perawat (Hadiyanto, 2020). Berdasarkan studi di Rumah Sakit Paru Dr. M. Goenawan Partowidigdo Cisarua Bogor menunjukkan bahwa rumah sakit yang memiliki sistem remunerasi lebih berpotensi meningkatkan motivasi pegawai dan meningkatkan kualitas pelayanan di rumah sakit dibanding rumah sakit yang tidak mempunyai sistem remunerasi berbasis kinerja (Hartono et al., 2019).

Pada penelitian ini menunjukkan bahwa motivasi kerja mempunyai pengaruh yang signifikan terhadap kinerja perawat. Hal ini didukung dengan penelitian yang dilakukan di RSUD Alimuddin Umar Kabupaten Lampung Barat yang menyatakan bahwa motivasi berpengaruh terhadap kinerja (Zainaro et al., 2017). Selain itu, penelitian yang dilakukan oleh Harfah et al., (2019) di RSUD Deli Serdang juga memberikan hasil bahwa motivasi kerja mempunyai pengaruh yang signifikan terhadap kinerja perawat.

\section{Pengaruh Sistem Remunerasi terhadap Motivasi dan Kinerja}

Sistem remunerasi dibuat sedemikian rupa untuk dapat meningkatkan penyelesaian tugas dan tanggung jawab masing-masing pegawai, serta ukuran atau target yang telah dicapai, dengan serangkaian proses yang dapat memicu kebangkitan individu, mengarahkan dan menjaga perilaku manusia menuju pencapaian tujuan pada periode tertentu. Sistem remunerasi diharapkan dapat memberikan motivasi kerja karyawan untuk memberikan prestasi kerja yang lebih tinggi. Prestasi kerja akan diukur berdasarkan penilaian kinerja yang diberikan standar capaian dari organisasi (Siahaan \& Meilani, 2019).

Kinerja merupakan catatan terhadap hasil produksi dari sebuah pekerjaan tertentu atau aktivitas tertentu dalam periode waktu tertentu (Karem et al., 2019). Kinerja juga memberikan umpan balik kepada karyawan dengan tujuan memotivasi karyawan tersebut untuk menghilangkan kemerosotan kinerja atau berkinerja dan meningkatkan kinerja lebih tinggi lagi dibanding sebelumnya (Sonoda et al., 2018). Kinerja menghasilkan sesuatu yang dicapai seseorang baik kualitas maupun kuantitas sesuai dengan tanggungjawab yang diberikan kepadanya. Selain itu kinerja seseorang dipengaruhi oleh tingkat pendidikan, inisiatif, pengalaman kerja, motivasi dan remunerasi (Tran et al., 2018). Oleh karena itu, dapat disimpulkan bahwa kinerja merupakan hasil yang dapat dicapai oleh seseorang dalam kurun waktu tertentu sesuai dengan tugasnya yang mengarah pada suatu tujuan organisasi.

Penelitian ini menunjukkan hasil bahwa faktor yang mempengaruhi kinerja pegawai adalah motivasi kerja yang tinggi dan dukungan sistem remunerasi. Penelitian ini setidaknya memberikan dukungan tentang teori bahwa kekuatan organisasi terletak pada manusia, bukan pada sistemnya, teknologi, prosedurnya atau sumber dananya. Sumber daya manusia yang berkualitas berdampak terhadap kinerja yang tinggi bagi organisasi.

Hasil uji statistik menunjukkan bahwa sistem remunerasi tidak memiliki pengaruh signifikan terhadap kinerja perawat, ini disebabkan karena sistem remunerasi sebagai reward belum tentu bisa memuaskan keinginan individu karyawan terhadap penghargaan dan karena umpan balik apresiatif terhadap kinerja perawat terbukti lebih mampu meningkatkan motivasi perawat dalam bekerja (Jalal \& Zaheer, 2017).

Hasil penelitian ini sejalan dengan penelitian yang dilakukan oleh Pratama \& Prasetya (2017) yang mengemukakan bahwa sistem remunerasi berbasis kinerja dapat berpengaruh terhadap kepuasan kerja dan nantinya akan berdampak pula terhadap motivasi kerja. Hal ini dapat diartikan ketika kepuasan kerja meningkat maka motivasi 
kerja meningkat pula. Imbalan berupa remunerasi dalam praktiknya di lapangan menjadi unsur yang sangat perlu untuk selalu dipertimbangkan dalam usaha meningkatkan kepuasan kerja dan meningkatkan pelayanan perawat kepada pasiennya.

Akan tetapi, hal tersebut berbeda dengan pendapat Juairiah \& Malwa (2016) yang mengemukakan bahwa terdapat hubungan yang sangat kuat antara variabel remunerasi dengan variabel kinerja pegawai, artinya kinerja pegawai tidak dapat tercapai secara optimal apabila remunerasi tidak diberikan secara proporsional. Penelitian dengan hasil yang sama dari penelitian Meilinda et al., (2019) menunjukkan bahwa terdapat pengaruh positif dan signifikan antara remunerasi dan budaya kerja terhadap kinerja pegawai.

Memotivasi perilaku yang berkaitan dengan pekerjaan akan berkaitan dengan usaha mencapai tujuan-tujuan organisasi sehingga dapat meningkatkan kinerja. Hasil ini sejalan dengan penelitian Bima (2017) yang menyatakan bahwa motivasi kerja berpengaruh secara positif dan signifikan terhadap kinerja. Proses meningkatkan motivasi pegawai untuk bertindakan dan mencapai tugas yang diinginkan tidaklah mudah. Salah satu cara untuk meningkatkan motivasi pegawai yaitu dengan menggunakan cara - cara yang efektif dan efisien yaitu dengan meningkatkan sistem remunerasi berbasis kinerja sehingga dapat meningkatkan motivasi yang membuat pekerja lebih baik dengan berkomitmen untuk pekerjaan mereka.

\section{SIMPULAN}

Sistem remunerasi memiliki pengaruh yang signifikan pada motivasi perawat dan motivasi memiliki pengaruh yang signifikan terhadap kinerja perawat di Rumah Sakit Swasta Jawa Timur, sehingga sistem remunerasi dapat mempengaruhi kinerja melalui motivasi.

\section{SARAN}

Berdasarkan hasil penelitian yang telah dipaparkan, saran yang diberikan kepada rumah sakit dengan harapan dapat bermanfaat bagi semua pihak yang berkepentingan. Ada pun saran yang kami kemukakan sebagai berikut:

Pihak Rumah Sakit meningkatkan motivasi kerja perawat melalui pemberian gaji atau remunerasi yang sesuai dengan performance masing-masing individu sehingga berdampak pada kinerja perawat yang semakin optimal.

Formulir KPI bisa dijadikan acuan untuk pemberian remunerasi berdasarkan penilaian kinerja dengan pelaksanaan teknis sebagai berikut: (1) Formulir KPI dinilai oleh atasan langsung untuk setiap perawat di unit masing-masing. (2) Formulir KPI yang telah dinilai diserahkan ke HRD di awal bulan (misalnya di tanggal 5) untuk penilaian bulan sebelumnya. (5) Pembagian hasil remunerasi berdasarkan penilaian kinerja akan diberikan tiap pertengahan bulan (misalnya tanggal 15) kepada masing-masing perawat.

Pihak Rumah Sakit menetapkan pegawai yang tidak mendapatkan reward antara lain: (1) Perawat yang mendapatkan Surat Peringatan (SP) tidak mendapatkan remunerasi terhitung masa berlakunya SP tersebut. (2) Perawat yang tidak melaksanakan tugasnya dikarenakan cuti maka tidak mendapatkan remunerasi terhitung lama waktunya cuti. 


\section{DAFTAR PUSTAKA}

Azizah, L. K., Bachri, A. A., \& Adenan, A. (2017). Pengaruh Pay Satisfaction Sistem Remunerasi Dan Motivasi Terhadap Kinerja Pegawai. Jurnal Berkala Kesehatan, 1(2), 60. DOI: https://doi.org/10.20527/jbk.v1i2.3144

Baljoon, R., Banjar, H., \& Banakhar, M. (2018). Nurses' Work Motivation and the Factors Affecting It: A Scoping Review. International Journal of Nursing \& Clinical Practices, 5(1), 1-10. https://doi.org/10.15344/2394-4978/2018/277

Dyah, L. A. S., Setiawan, M., Irawanto, D. W., Rohman, F., \& Nursalam, N. (2020). Analysis Factors of Nursing Performance at the Mother and Child Hospital in East Java. Indian Journal of Public Health Research \& Development, 11(3), 2103-2108. https://medicopublication.com/index.php/ijphrd/article/view/2419

Hadiyanto. (2020). Pengaruh Remunerasi, Motivasi Pegawai, dan Kinerja Pegawai terhadap Kinerja Organisasi. Jurnal Pengawasan, 2(1), 52-60. http://www.bpkp.go.id/public/upload/unit/puslitbangwas/files/Remunerasi dll pada Kinerja Organisasi.pdf

Harfah, N., Muttaqin, M., \& Halim, H. (2019). Pengaruh Motivasi Kerja terhadap Kinerja Perawat di Unit Rawat Inap Rumah Sakit Umum Daerah Kota Makassar. https://pdfcoffee.com/pengaruh-motivasi-kerja-terhadap-kinerja-perawatpdf-pdffree.html

Hartono, B., Sulaeman, S., Nopianna, I., \& Sari, K. (2019). Pengaruh Sistem Remunerasi Terhadap Motivasi Kerja, Kepuasan Kerja dan Dampaknya Terhadap Kinerja Perawat di RS Paru Gunawan Tahun 2018. Jurnal Keperawatan Muhammadiyah, 4(2), 24-30. http://103.114.35.30/index.php/JKM/article/view/2740/2285

Hidayah, N., \& Dewi, A. (2021). Pemetaan Analisis Jabatan dan Penilaian Kinerja sebagai Dasar Pengembangan Sistem Remunerasi. Berdikari: Jurnal Inovasi dan Penerapan Ipteks, 9(1), 77-86. https://doi.org/10.18196/berdikari.v9i1.6500

Hidayah, N., Dewi, A., \& Listiowati, E. (2020). Remuneration as a Strategy to Improve Service Quality, Cost-Effectiveness, and Organizational Performance of Private Hospitals. Enfermería Clínica, 30, 179-182. https://doi.org/https://doi.org/10.1016/j.enfcli.2020.06.077

Jalal, R. N.-U.-D., \& Zaheer, M. A. (2017). Does Job Satisfaction Mediate the Relationship of Workload, Remuneration and Psychological Reward with Job Performance? International Journal of Academic Research in Business and Social Sciences, 7(9). https://doi.org/10.6007/ijarbss/v7-i9/3309

Juairiah, J., \& Malwa, R. U. (2016). Hubungan antara Pemberian Remunerasi terhadap Kinerja Karyawan di Rumah Sakit Islam Siti Khadijah Palembang. Psikis: Jurnal Psikologi Islami, 2(2). http://jurnal.radenfatah.ac.id/index.php/psikis/article/view/1187

Karem, M. A., Mahmood, Y. N., Jameel, A. S., \& Ahmad, A. R. (2019). The Effect of Job Satisfaction and Organizational Commitment on Nurses' Performance. Humanities and Social Sciences Reviews, 7(6), 332-339. DOI: https://doi.org/10.18510/hssr.2019.7658

Lesmana, M. T., \& Putri, L. P. (2017). Pengaruh Kemampuan dan Motivasi terhadap Kinerja Perawat: Studi pada Rumah Sakit Umum Madani Medan. Jurnal Riset Sains Manajemen, 1(3), 97-102. https://doi.org/10.5281/zenodo.1036809 
Li, K. C., Lee, L. Y. K., Wong, S. L., Yau, I. S. Y., \& Wong, B. T. M. (2018). Effects of Mobile Apps for Nursing Students: Learning Motivation, Social Interaction and Study Performance. Open Learning, 33(2), 99-114. https://doi.org/10.1080/02680513.2018.1454832

Maini, R. (2020). Health Workers in the Democratic Republic of Congo: An Exploration of Their Motivation, Incentives, and the Effects of an Intervention to Improve Their Remuneration by Government. London School of Hygiene \& Tropical Medicine, 2(2), 101-110. https://doi.org/https://doi.org/10.17037/PUBS.04657205

Meilinda, H., Budianto, A., \& Kader, M. A. (2019). Pengaruh Remunerasi dan Budaya Kerja terhadap Kinerja Pegawai (Suatu Studi pada Balai Besar Wilayah Sungai Citanduy Banjar). Business Management and Entrepreneurship Journal, 1(3), 141154. https://jurnal.unigal.ac.id/index.php/bmej/article/view/2322

Mendes, A., Lunkes, R. J., Flach, L., \& Kruger, S. D. (2017). The Influence of Remuneration on the Behavior of Hospital Employees in Brazil. Contaduria $y$ Administracion, 62(1), 207-221. https://doi.org/10.1016/j.cya.2016.04.005

Muthmainnah, M., Hamid, A. Y. S., \& Hariyati, R. T. S. (2018). Improving Nurses' Performance Through Remuneration: A Literature Review. Enfermeria Clinica, 28(1), 130-133. https://doi.org/10.1016/S1130-8621(18)30052-4

Permatasari, N. I., Nurbaeti, N., \& Ahri, R. A. (2021). Pengaruh Remunerasi terhadap Kinerja Perawat di Ruang Rawat Inap RSUD Labuang Baji Kota Makassar. Window of Public Health Journal, 1(5), 493-501. https://media.neliti.com/media/publications/340549-pengaruh-remunerasi-terhadapkinerja-per-4a54f41b.pdf

Pratama, T. W. Y., Tamtomo, D., \& Sulaeman, E. S. (2018). Factors Associated with the Completeness of Inpatient Medical Record Filling in Dr. R Sosodoro Djatikoesoemo, Bojonegoro, East Java. Journal of Health Policy and Management, 3(1), 1-10. https://doi.org/10.26911/thejhpm.2018.03.01.01

Pratama, W., \& Prasetya, A. (2017). Pengaruh Sistem Remunerasi terhadap Kepuasan Kerja dan Motivasi Kerja pada Perguruan Tinggi. Jurnal Administrasi Bisnis S1 Universitas Brawijaya, 46(1), 52-60. http://administrasibisnis.studentjournal.ub.ac.id/index.php/jab/article/view/1782

Siahaan, Y. L. O., \& Meilani, R. I. (2019). Sistem Kompensasi dan Kepuasan Kerja Guru Tidak Tetap di Sebuah SMK Swasta di Indonesia. Jurnal Pendidikan Manajemen Perkantoran, 4(2), 141. https://doi.org/10.17509/jpm.v4i2.18008

Sonoda, Y., Onozuka, D., \& Hagihara, A. (2018). Factors Related to Teamwork Performance and Stress of Operating Room Nurses. Journal of Nursing Management, 26(1), 66-73. https://doi.org/10.1111/jonm.12522

Teja, S. G. B. H. (2017). Pengaruh Remunerasi dan Motivasi Kerja terhadap Kinerja Karyawan (Studi Kasus pada Kantor Pengawasan dan Pelayanan Bea Dan Cukai Surakarta). Daya Saing Jurnal Ekonomi Manajemen Sumber Daya, 19(2), 109-118. https://journals.ums.ac.id/index.php/dayasaing/article/view/5439

Tong, L. (2018). Relationship Between Meaningful Work and Job Performance in Nurses. International Journal of Nursing Practice, 24(2), 1-6. https://doi.org/10.1111/ijn.12620

Tran, K. T., Nguyen, P. V., Dang, T. T. U., \& Ton, T. N. B. (2018). The Impacts of the High-Quality Workplace Relationships on Job Performance: A Perspective on Staff Nurses in Vietnam. Behavioral Sciences, 8(12), 5-12. https://doi.org/10.3390/bs8120109 
Wati, T. V. (2018). Model Renumerasi Staf Medis Spesialis di RSUP Sanglah. Jurnal Manajemen dan Bisnis, 15(4), 127-153. DOI: https://doi.org/10.38043/jmb.v15i4.2285

Zainaro, M. A., Isnainy, U. C. A. S., Furqoni, P. D., \& Wati, K. (2017). Pengaruh Motivasi Kerja terhadap Kinerja Perawat Pelaksana di Ruang Rawat Inap Rumah Sakit Umum Daerah Alimuddin Umar Kabupaten Lampung Barat Tahun 2017. HJK: Holistik Jurnal Kesehatan, 11(4), 209-215. http://ejurnalmalahayati.ac.id/index.php/holistik/article/view/130 